\title{
PERANCANGAN DECISION SUPPORT SYSTEM PADA BIBIT SALAK BERBASIS SIMPLE ADDITTIVE WEIGHTING
}

\section{Teri Mengkasrinal}

\author{
Program Studi Manajemen Informatika \\ Akademi Manajemen Informatika \& Komputer (AMIK) "Boekittinggi" \\ email: mengkasrinal110@gmail.com
}

\begin{abstract}
Computers have a system that has the ability to help people in solving problems, with their decision support systems can improve the quality of decision support system that will be created. For example, the bark berkualitas.Sistem seed selection to be made in the decision making is by using SAW (Simple Additive Weighting). These applications seek a weighted summation of the performance rating for each alternative on all attributes, and requires a decision matrix normalization process to a scale that can be compared with all the ratings of existing alternatives. The report will describe the decision support system in the process of selection of seeds with good quality bark. Application of the method of this SAW, obtained seeds of good quality bark and accurately.
\end{abstract}

Keywords: Decision Support Systems, Seed Salak, SAW

\section{Pendahuluan}

Banyak kegiatan yang harus di perhatikan pada pemilihan bibit tanaman salak, salah satu faktor yang perlu diperhatikan dalam usaha pembibitan salak adalah penggunaan bibit unggul. Tanaman salak merupakan tanaman tahunan, karena itu kesalahan dalam pemakaian bibit akan berakibat buruk terhadap penghasilan masyarakat. Perlakuan dan teknis yang baik tidak akan memberikan hasil maksimal sesuai dengan yang diinginkan, sehingga modal yang dikeluarkan tidak akan kembali karena adanya kerugian. Untuk itu pemilihan bibit dan penegcekan bibit harus dilakukan sebelum ditanam. Ciri-ciri dan kriteria setiap jenis bibit berbeda, dengan adanya perbedaan inilah sering mengakibatkan hasil produksi juga bermacam-macam dan tergantung kepada bibit salak tersebut.

Salah satu penyebabnya adalah masyarakat sebetulnya membutuhkan sebuah teknologi dalam menentukan jenis bibit yang tepat untuk mereka budidayakan. Dalam menghadapi kendala pemilihan bibit salak yang berkualitas dapat dilakukan dengan menggunakan metode Simple Additive Weighting (SAW). Metode ini merupakan salah satu metode dalam mengambil keputusan untuk mencari alternatif yang optimal dari kriteria-kriteria yang ada. Dengan alur algoritma yang sederhana tetapi dapat menjadi bahan solusi terhadap permasalahan dalam menentukan bibit salak yang berkualitas baik.

\section{Rumusan Masalah}

a. Bagaimana menerapkan metode Simple Additive Weight (SAW) pada Sistem Pendukung Keputusan (SPK) dalam pemilihan Bibit Salak?

b. Bagaimana merancang aplikasi Sistem Pendukung Keputusan (SPK) untuk memilih bibit salak dengan metode Simple Additive Weight (SAW)?

c. Apakah penerapan sistem pendukung keputusan pemilihan bibit salak sudah efektif dan efisien?

\section{Tujuan dan Maksud}

a. Untuk menerapkan metode Simple Additive Weighting (SAW) pada Sistem Pendukung Keputusan (SPK) dalam pemilihan bibit salak.

b. Untuk merancang aplikasi Sistem Pendukung Keputusan (SPK) untuk memilih bibit salak dengan metode Simple Additive Weighting (SAW)

Adapun Maksud Penelitian ini adalah:

1. Menambah wawasan dan pengetahuan tentang penelitian dalam bidang pembibitan salak selanjutnya akan 
dapat lebih cermat dalam melakukan penelitian berikutnya.

2. Mempermudah pemilik usaha dalam pemilihan bibit salak yang akan di tawarkan kepada masyarakat .

3. Mempermudah mengetahui pemilihan bibit salak dalam waktu yang relatif singkat.

\section{Teori Pendukung}

Definisi klasik lainnya yaitu "Sistem pendukung keputusan memadukan sumber daya intelektual dari individu dengan kapabilitas komputer untuk meningkatkan kualitas keputusan. Sistem pendukung keputusan adalah sistem pendukung berbasis komputer bagi para pengambil keputusan manajemen yang menangani masalah-masalah tidak terstruktur". (Turban, 2005). Jenis-jenis keputusan menurut (Herbert A. Simon ) :

a. Keputusan Terprogram, Keputusan ini bersifat berulang dan rutin, sedemikian hingga suatu prosedur pasti telah dibuat menanganinya.

b. Keputusan Tidak Terprogram, Keputusan ini bersifat baru, tidak terstruktur dan jarang konsekuen.

Tahap-tahap Pengambilan Keputusan menurut Herbet A. Simon.

a. Tahap Intelligence, Tahap intelligence adalah tahap pengakuan adanya masalah.

b. Tahap Design, Tahap Design adalah tahap perancangan berbagai alternatif yang akan dipilih.

c. Tahap Choice, Tahap choice adalah tahap memilih salah satu diantara berbagai alternatif yang sudah disiapkan dalam tahap design.

d. Tahap implementation, Setelah memutuskan untuk memilih salah satu alternatif, maka manajemen melaksanakan keputusan itu.

Menurut (Kusrini, 2007) yaitu

a. Membantu manajer dalam pengambilan keputusan atas masalah semi terstruktur.

b. Memberikan dukungan atas pertimbangan manajer dan bukannya dimaksudkan untuk menggantikan fungsi manajer.

c. Meningkatkan efektivitas keputusan yang diambil manajer lebih dari pada perbaikan efisiensinya.

Metode SAW membutuhkan proses normalisasi matriks keputusan (X) ke suatu skala yang dapat diperbandingkan dengan semua rating alternatif yang ada. Metode ini merupakan metode yang paling terkenal dan paling banyak digunakan dalam menghadapi situasi Multiple Attribute Decision Making (MADM). MADM itu sendiri merupakan suatu metode yang digunakan untuk mencari alternatifoptimal dari sejumlah alternatif dengan kriteria tertentu.

Metode SAW ini mengharuskan pembuat keputusan menentukan bobot bagi setiap atribut. Skor total untuk alternatif diperoleh dengan menjumlahkan seluruh hasil perkalian antara rating (yang dapat dibandingkan lintas atribut) dan bobot tiap atribut. Rating tiap atribut haruslah bebas dimensi dalam arti telah melewati proses normalisasi matriks sebelumnya. Langkah Penyelesaian SAW sebagai berikut :

a. Menentukan kriteria-kriteria yang akan dijadikan acuan dalam pengambilan keputusan, yaitu Ci.

b. Menentukan rating kecocokan setiap alternatif pada setiap kriteria.

c. Membuat matriks keputusan berdasarkan criteria (Ci), kemudian melakukan normalisasi matriks berdasarkan persamaan yang disesuaikan dengan jenis atribut (atribut keuntungan ataupun atribut biaya) sehingga diperoleh matriks ternormalisasi R.

d. Hasil akhir diperoleh dari proses perankingan yaitu penjumlahan dari perkalian matriks ternormalisasi $\mathrm{R}$ dengan vektor bobot sehingga diperoleh nilai terbesar yang dipilih sebagai alternatif terbaik (Ai) sebagai solusi.

Formula untuk melakukan normalisasi tersebut adalah :

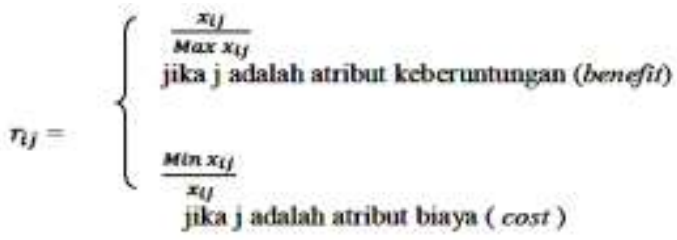

Persamaan.

Dimana :

rij = rating kinerja ternormalisasi

Maxij = nilai maksimum dari setiap baris dan kolom

Minij = nilai minimum dari setiap baris dan kolom

$\mathrm{Xi} \mathrm{j}=$ baris dan kolom dari matriks

Benefit $=$ jika nilai terbesar adalah terbaik

Cost $=$ jika nilai terkecil adalah terbaik 
Dengan rij adalah rating kinerja ternormalisasi dari alternatif Ai pada atribut $\mathrm{Cj} ; \mathrm{i}=1,2, \ldots \mathrm{m}$ dan $\mathrm{j}=1,2, \ldots, \mathrm{n}$. Nilai preferensi untuk setiap alternative (Vi) sebagai berikut :

$$
\mathrm{V}_{\mathrm{i}}=\sum_{\mathrm{j}=1}^{\mathrm{n}} \mathrm{w}_{\mathrm{j}} \mathbf{r}_{\mathrm{ij}}
$$

Persamaan.

Dimana :

$\mathrm{Vi}=$ Nilai akhir dari alternatif

$\mathrm{wj}=$ Bobot yang telah ditentukan

rij $=$ Normalisasi matriks

Nilai Vi yang lebih besar mengindikasikan bahwa alternatif Ai lebih

\section{Metode Penelitian}

Menggunakan metode analisa yang umum dibidang komputer yaitu System Development Life Cycle (SLDC). Adapun fase-fase analisa tersebut antara lain :

1. Perencanaan Sistem (System Planning), Merencanakan sistem yang akan dikembangkan sesuai dengan perumusan masalah yang didapat, kemudian mendefenisikan masalah yang ada untuk ditinjau lebih lanjut sehingga terkait dengan tahapan selanjutnya.

2. Analisis Sistem (System Analyze), Dari proses analisa ini akan didapatkan cara untuk membangun sistem baru dengan cara menganalisa sistem yang lama dengan mengidentifikasi masalah, memahami masalah, serta menganalisis masalah sesuai dengan permasalahan yang ada dan membangun sistem yang baru dengan tidak merubah sistem lama secara keseluruhan.

3. Desain Sistem Secara Umum (Design Logic), Merupakan proses penentuan cara kerja sistem dalam hal desain arsitektur, desain antar muka, basis data, spesikasi file dan desain program. Hasil dari proses perancangan sistem ini akan didapatkan spesifikasi sistem

4. Evaluasi dan Seleksi Sistem. Menterjemahkan atau memetakan hasil rancangan sistem kedalam suatu teknologi dimana para analis mengevaluasi dan menyeleksi sistem yang telah dirancang secara terinci, seperti menyeleksi bahasa pemograman, database, software, sistem operasi dan spesifikasi hardware yang digunakan dalam pengembangan sistem.
5. Desain Sistem Secara Rinci (Design Phisyc), Analis mengevaluasi dan menyeleksi sistem yang telah dirancang secara terinci. Seperti menyeleksi bahasa pemograman, database, software, sistem operasi, dan spesifikasi hardware yang digunakan pengembangan sistem.

6. Implementasi (Implementation), Proses pembangunan dan pengajian sistem, instalasi sistem, dan rencana dukungan sistem. Sistem yang telah dirancang kemudian dikoding, diuji, dan installasi.

Perawatan Sistem (Maintanance), Merupakan tahapan akhir dimana data dapat dipastikan bahwa secara sistematik sistem informasi dapat diperbaiki dan dikembangkan.

7. Desain Sistem Secara Rinci (Design Phisyc), Analis mengevaluasi dan menyeleksi sistem yang telah dirancang secara terinci. Seperti menyeleksi bahasa pemograman, database, software, sistem operasi, dan spesifikasi hardware yang digunakan pengembangan sistem.

8. Implementasi (Implementation), Proses pembangunan dan pengajian sistem, instalasi sistem, dan rencana dukungan sistem. Sistem yang telah dirancang kemudian dikoding, diuji, dan installasi.

Perawatan Sistem (Maintanance), Merupakan tahapan akhir dimana data dapat dipastikan bahwa secara sistematik sistem informasi dapat diperbaiki dan dikembangkan.

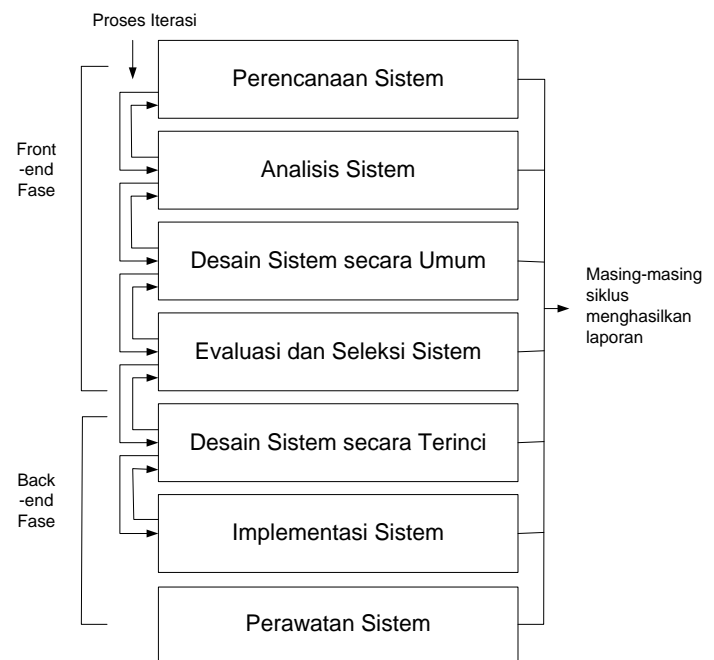

Gambar. 1 System Development Life Cyle (SLDC) 


\section{Pembahasan}

Pada aliran sistem informasi baru ini dapat dilihat beberapa perubahan dari sistem lama.

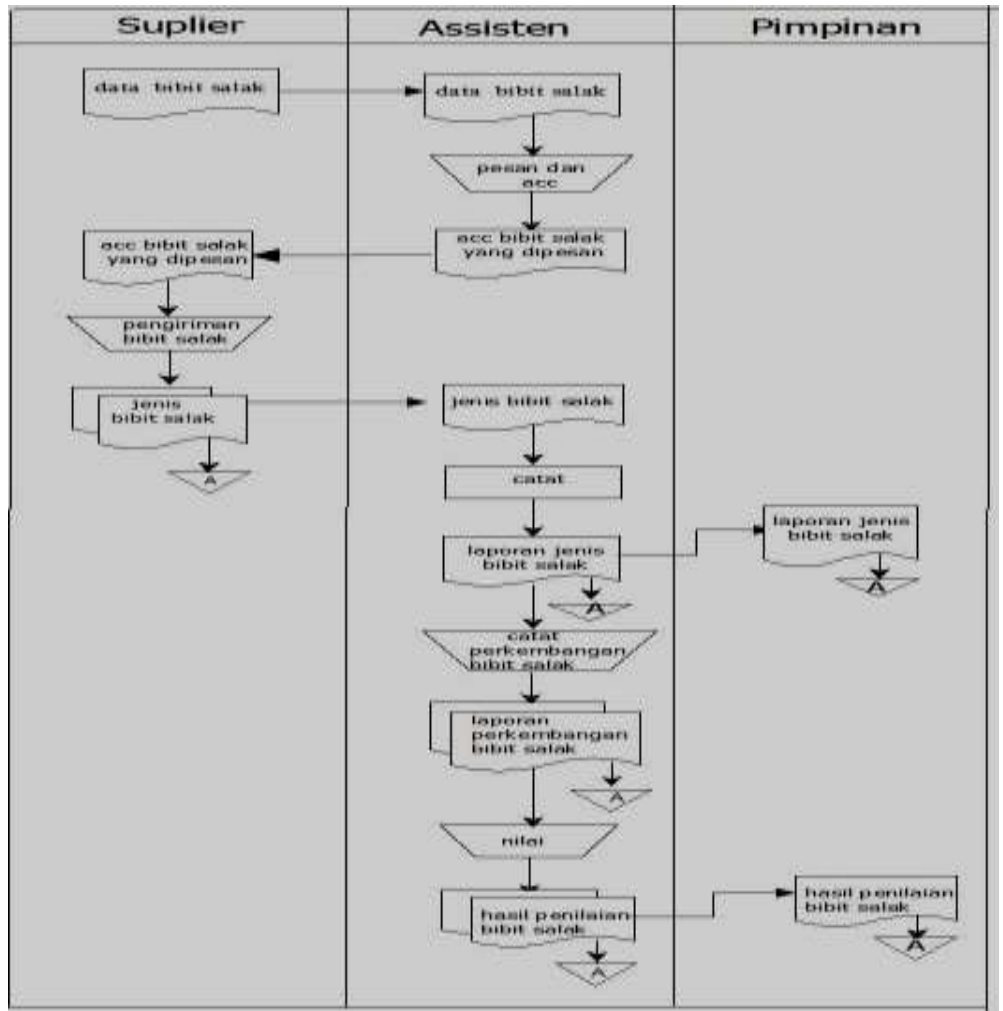

Gambar 2 Aliran Sistem Informasi Lama

Pada menerapkan sistem baru ini dengan baik dibutuhkan pegawai yang sudah terlatih agar tidak terjadi kesalahan dalam pemakaiannya dan sesuai dengan prosedur yang benar.

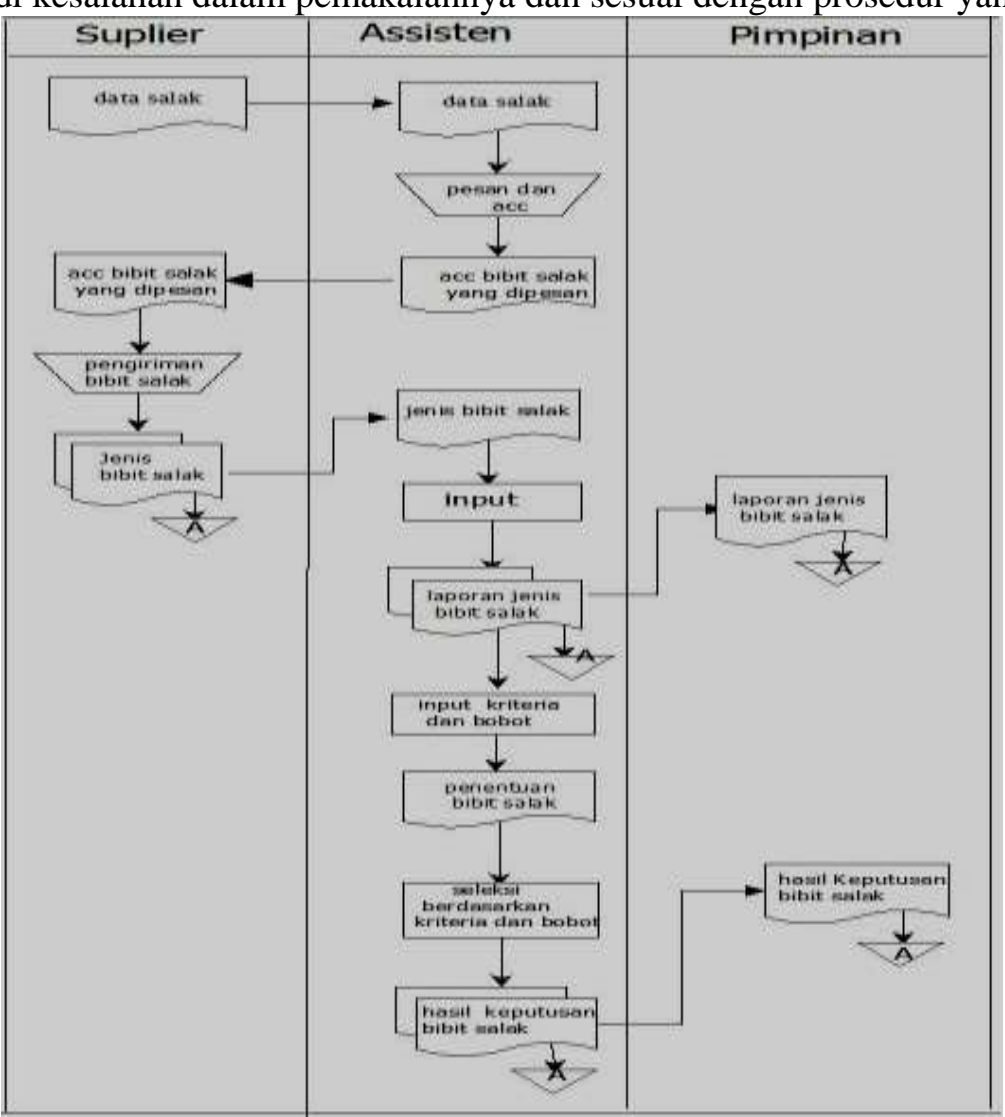

Gambar 3 Aliran Sistem Informasi Baru 
Untuk menggambarkan sistem secara keseluruhan, DFD yang menjelaskan gambaran logika pembuatan sistem informasi secara umum.

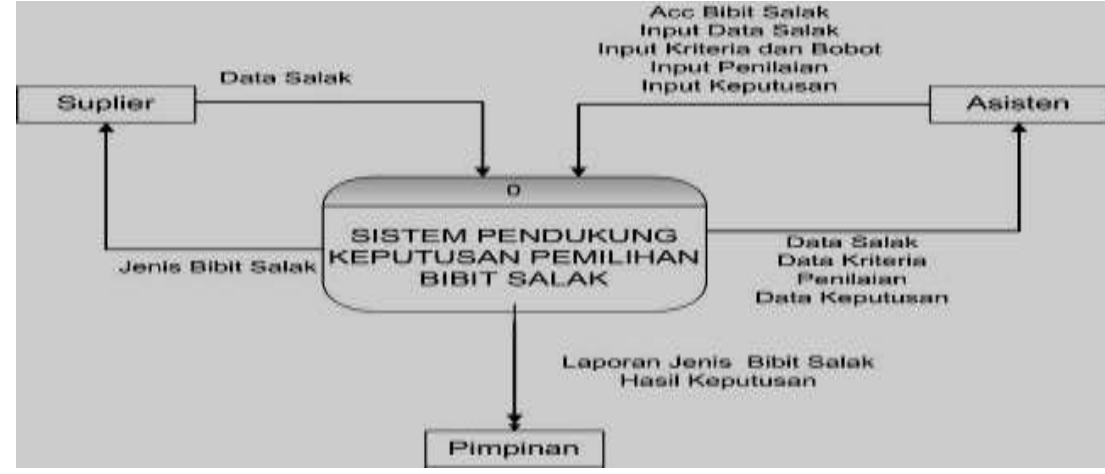

Gambar 4 Context Diagram

Untuk menjelaskan secara detail kerja sistem dibutuhkan Data flow sebagai pemodelan rancangan global logika pembuatan software sistem informasi.

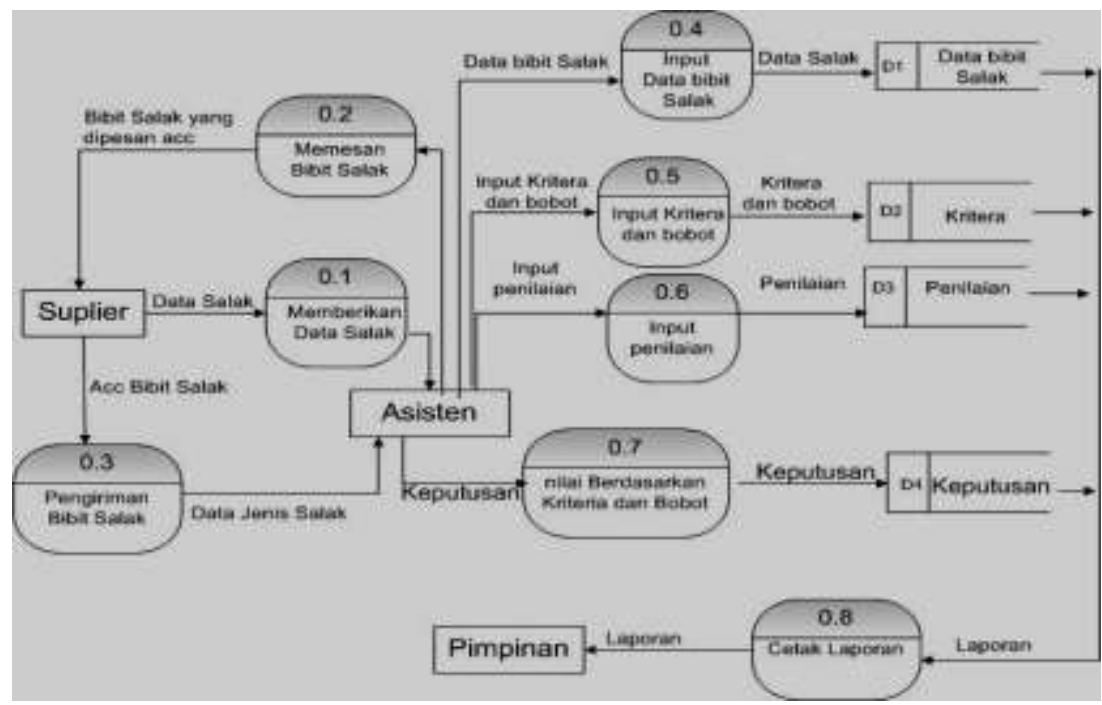

Gambar 5 Flow Diagram

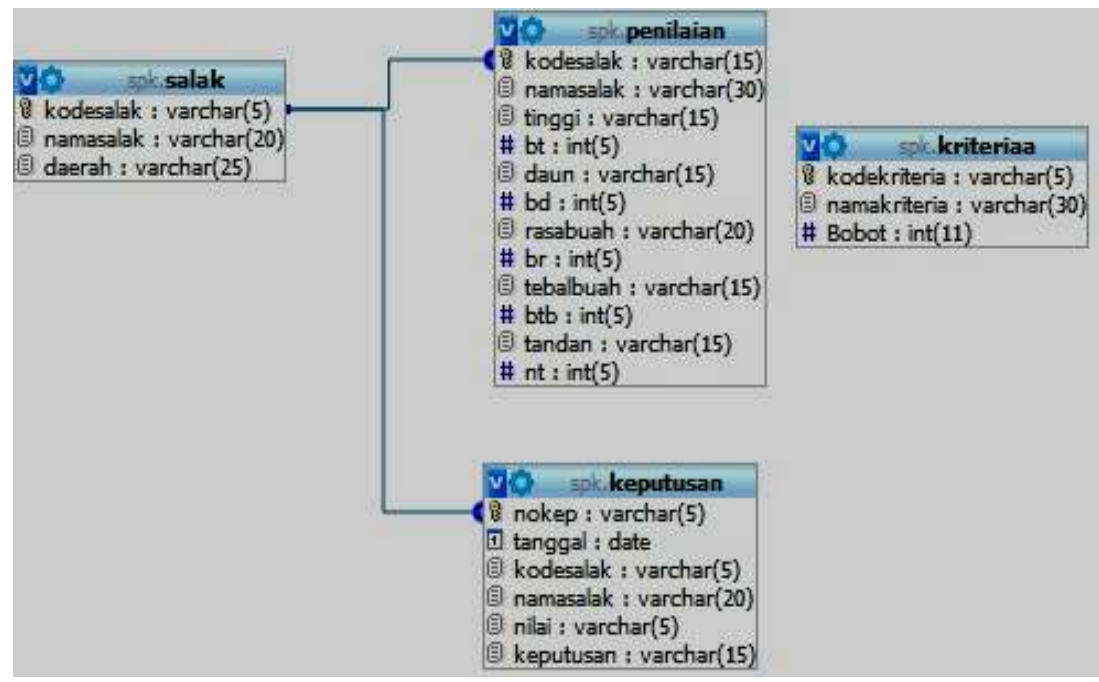

Gambar 6 Relasi Antar Tabel 
Analisis Penerapan metode simple additive weighting

1. Alternatif pemiihan Jenis bibit salak:

2. Daun

Tabel 1. Nama Salak dan Kode

\begin{tabular}{|l|c|}
\hline \multicolumn{1}{|c|}{ Nama Salak } & Kode Salak \\
\hline Salak Condet & A1 \\
\hline Salak Madu & A2 \\
\hline Salak Pondoh & A3 \\
\hline Salak Sidempuan & A4 \\
\hline
\end{tabular}

Tabel 5. Daun, Bobot dan Nilai

\begin{tabular}{|c|l|c|c|}
\hline No & \multicolumn{1}{|c|}{ Daun } & Bobot & Nilai \\
\hline 1 & $2-3 \mathrm{~m}$ & Cukup & 1 \\
\hline 2 & $2,5-3,5 \mathrm{~m}$ & Sedang & 2 \\
\hline 3 & $3-4 \mathrm{~m}$ & Tinggi & 3 \\
\hline 4 & $4-6 \mathrm{~m}$ & Sangat Tinggi & 4 \\
\hline
\end{tabular}

2. Kriteria dan Pembobotan

a) Kriteria

3. Rasa Buah

Tabel 2. Kriteria Salak

\begin{tabular}{|l|c|}
\hline \multicolumn{1}{|c|}{ Keterangan } & Kriteria \\
\hline Tinggi & CI \\
\hline Daun & C2 \\
\hline Rasa Buah & C3 \\
\hline Tebal Daging Buah & C4 \\
\hline Jumlah Buah Pertandan & C5 \\
\hline
\end{tabular}

b) Bobot

Tabel 6. Rasa Buah

\begin{tabular}{|c|l|l|c|}
\hline No & \multicolumn{1}{|c|}{ C3 } & Bobot & Nilai \\
\hline 1 & $\begin{array}{l}\text { Manis dan } \\
\text { Asam }\end{array}$ & Cukup & 1 \\
\hline 2 & Manis dan Gurih & Sedang & 2 \\
\hline 3 & $\begin{array}{l}\text { Manis dan } \\
\text { Wangi }\end{array}$ & Tinggi & 3 \\
\hline 4 & $\begin{array}{l}\text { Manis Seperti } \\
\text { Madu }\end{array}$ & $\begin{array}{l}\text { Sangat } \\
\text { Tinggi }\end{array}$ & 4 \\
\hline
\end{tabular}

4. Tebal Daging Buah

Tabel 3. Pembobotan

\begin{tabular}{|l|c|}
\hline \multicolumn{1}{|c|}{ Bobot } & Nilai \\
\hline Cukup/Manis Dan Asam & 1 \\
\hline Sedang/Manis & 2 \\
\hline Tinggi/Manis dan Wangi & 3 \\
\hline $\begin{array}{l}\text { Sangat Tinggi/Manis Seperti } \\
\text { Madu }\end{array}$ & 4 \\
\hline
\end{tabular}

Tabel 7. Tebal Daging Buah

\begin{tabular}{|c|c|c|c|}
\hline No & C4 & Bobot & Nilai \\
\hline 1 & $0,4-0,6 \mathrm{~cm}$ & Cukup & 1 \\
\hline 2 & $0,5-1,5 \mathrm{~cm}$ & Sedang & 2 \\
\hline 3 & $0,6-2,0 \mathrm{~cm}$ & Tinggi & 3 \\
\hline 4 & $0,8-1,5 \mathrm{~cm}$ & Sangat Tinggi & 4 \\
\hline
\end{tabular}

5. Jumlah Pertandan

Kriteria dan bobot nilai ditentukan dalam pemilihan bibit :

1. Tinggi

Tabel 8. Jumlah Pertandan

\begin{tabular}{|c|c|c|c|}
\hline No & C5 & Bobot & Nilai \\
\hline 1 & $14-20$ buah & Cukup & 1 \\
\hline 2 & $30-45$ buah & Sedang & 2 \\
\hline 3 & $45-90$ buah & Tinggi & 3 \\
\hline 4 & $90-120$ buah & Sangat Tinggi & 4 \\
\hline
\end{tabular}

Tabel 4. Tinggi

\begin{tabular}{|c|l|l|c|}
\hline No & C1(meter) & Bobot & Nilai \\
\hline 1 & $1-1,5$ meter & Cukup & 1 \\
\hline 2 & $1,5-3$ meter & Sedang & 2 \\
\hline 3 & $3-4$ meter & Tinggi & 3 \\
\hline & $4-4,5$ meter & $\begin{array}{l}\text { Sangat } \\
\text { Tinggi }\end{array}$ & 4 \\
\hline
\end{tabular}

6. Adapun data hasil seleksi alternatif yang diajukan

Tabel 8. Jumlah Pertandan

\begin{tabular}{|c|l|c|c|c|c|c|}
\hline \multirow{2}{*}{ No } & \multirow{2}{*}{ Alternatif } & \multicolumn{5}{|c|}{ Kriteria } \\
\cline { 3 - 7 } & $\begin{array}{c}\text { Tinggi } \\
(\mathrm{m})\end{array}$ & $\begin{array}{c}\text { Daun } \\
(\mathrm{m})\end{array}$ & Rasa Buah & $\begin{array}{c}\text { Tebal Daging } \\
\text { Buah(m) }\end{array}$ & $\begin{array}{c}\text { Jumlah Buah } \\
\text { Pertandan }\end{array}$ \\
\hline 1 & Salak Condet & $4-4,5$ & $2,5-3,5$ & Manis dan Wangi & $0,5-1,5$ & $45-90$ \\
\hline 2 & Salak Madu & $3-4$ & $2-3$ & Manis seperti Madu & $0,4-0,6$ & $30-45$ \\
\hline 3 & Salak Pondoh & $1-1,5$ & $3-4$ & Manis dan Gurih & $0,8-1,5$ & $14-20$ \\
\hline 4 & Salak Sidempuan & $1,5-3$ & $4-6$ & Manis dan Asam & $0,6-2,0$ & $90-120$ \\
\hline
\end{tabular}


Menentukan rating kecocokan setiap alternatif pada setiap kriteria. Adapun data rating kecocokan dari setiap alternatif

Tabel 9. Kritris dari Beberapa Alternatif

\begin{tabular}{|c|l|c|c|c|c|c|}
\hline \multirow{2}{*}{ No } & \multirow{2}{*}{ Alternatif } & \multicolumn{5}{|c|}{ Kriteria } \\
\cline { 3 - 7 } & & $\mathbf{C 1}$ & $\mathbf{C 2}$ & $\mathbf{C 3}$ & $\mathbf{C 4}$ & C5 \\
\hline 1 & A1 & 4 & 2 & 3 & 2 & 3 \\
\hline 2 & A2 & 3 & 1 & 4 & 1 & 2 \\
\hline 3 & A3 & 1 & 3 & 2 & 4 & 1 \\
\hline 4 & A4 & 2 & 4 & 1 & 3 & 4 \\
\hline
\end{tabular}

Menormalisasikan matriks $\mathrm{X}$ menjadi matriks $\mathrm{R}$ berdasarkan persamaan 1

Alternatif : A1 (salak condet)

$$
\begin{aligned}
& \mathrm{r} 11=\frac{4}{\operatorname{Max}\{1,2,3,4)}=\frac{4}{4}=1,00 \\
& \mathrm{r} 12=\frac{2}{\operatorname{Max}\{1,2 ; 3 ; 4\}}=\frac{2}{4}=0,50 \\
& \mathrm{r} 13=\frac{3}{\operatorname{Max}\{1,2 ; 3 ; 4\}}=\frac{3}{4}=0,75 \\
& \mathrm{r} 14=\frac{2}{\operatorname{Max}\{1 ; 2 ; 3 ; 4)}=\frac{2}{4}=0,25 \\
& \mathrm{r} 15=\frac{3}{\operatorname{Max}\{1 ; 2 ; 3 ; 4)}=\frac{3}{4}=0,75
\end{aligned}
$$

\section{Alternatif : A3 (Salak Pondoh)}

$$
\begin{aligned}
& \mathrm{r} 31=\frac{1}{\operatorname{Max}\{1,2,3,4)}=\frac{1}{4}=0,25 \\
& \mathrm{r} 32=\frac{3}{\operatorname{Max}\{1,2 ; 3 ; 4\}}=\frac{3}{4}=0,75 \\
& \mathrm{r} 33=\frac{2}{\operatorname{Max}\{1,2 ; 3 ; 4\}}=\frac{4}{4}=0,50 \\
& \mathrm{r} 34=\frac{4}{\operatorname{Max}\{1 ; 2 ; 3 ; 4)}=\frac{4}{4}=1,00 \\
& \mathrm{r} 35=\frac{3}{\operatorname{Max}\{1 ; 2 ; 3 ; 4)}=\frac{3}{4}=0,75
\end{aligned}
$$

$$
\begin{aligned}
& \text { Alternatif : A2 (Madu) } \\
& \mathrm{r} 21=\frac{3}{\operatorname{Max}\{1,2,3,4)}=\frac{3}{4}=0,75 \\
& \mathrm{r} 22=\frac{1}{\operatorname{Max}\{1,2 ; 3 ; 4\}}=\frac{1}{4}=0,25 \\
& \mathrm{r} 23=\frac{4}{\operatorname{Max}\{1,2 ; 3 ; 4\}}=\frac{4}{4}=1,00 \\
& \mathrm{r} 24=\frac{1}{\operatorname{Max}\{1 ; 2 ; 3 ; 4)}=\frac{1}{4}=0,25 \\
& \mathrm{r} 25=\frac{2}{\operatorname{Max}\{1 ; 2 ;}=\frac{2}{4}=0,50
\end{aligned}
$$

Alternatif : A4 (Salak Sidempuan)

$$
\begin{aligned}
& \mathrm{r} 41=\frac{2}{\operatorname{Max}\{1,2,3,4)}=\frac{2}{4}=0,50 \\
& \mathrm{r} 42=\frac{4}{\operatorname{Max}\{1,2 ; 3 ; 4\}}=\frac{4}{4}=1,00 \\
& \mathrm{r} 43=\frac{1}{\operatorname{Max}\{1,2 ; 3 ; 4\}}=\frac{1}{4}=0,25 \\
& \mathrm{r} 44=\frac{4}{\operatorname{Max}\{1 ; 2 ; 3 ; 4)}=\frac{4}{4}=1,00 \\
& \mathrm{r} 45=\frac{3}{\operatorname{Max}\{1 ; 2 ; 3 ; 4)}=\frac{3}{4}=0,75
\end{aligned}
$$

Dari hasil perhitungan di atas maka diapat matriks ternomalisasi R sebagai berikut

$$
\text { Rij }=\left[\begin{array}{rccrr}
1 & 0,5 & 0,75 & 0,5 & 0,75 \\
0,75 & 0,25 & 1 & 0,25 & 0,5 \\
0,25 & 0,75 & 0,5 & 1 & 0,75 \\
0,5 & 1 & 0,25 & 1 & 0,75
\end{array}\right.
$$

Proses perangkingan diperoleh bersarkan persaman sebagai berikut:

Vector bobot: $\mathrm{W}=[3,2,4,3,4]$, Hasil akhir diperoleh dari perkalian matrik adalah:

$\mathrm{V} 1=(1 * 3)+(0.5 * 2)+(0,75 * 4)+(0,5 * 3)+(0,75 * 4)=3+1+3+1.5+3=11.5$

$\mathrm{V} 2=(0.75 * 3)+(0.25 * 02)+(1 * 4)+(0.25 * 3)+(0.5 * 4)=2.25+0.5+4+0.75+2=9.5$

$\mathrm{V} 3=(0.25 * 3)+(0.75 * 2)+(0.5 * 4)+(1 * 3)+(0,75 * 4)=0.75+1.5+2+3+3=8.25$

$\mathrm{V} 4=(0.5 * 3)+(1 * 2)+(0,25 * 4)+(1 * 3)+(0,75 * 4)=1.5+2+1+3+3=10.5$ 
Langkah terakhir adalah proses perankingan.Hasi lperankingan diperoleh:V1 $0.11 .5 ; \mathrm{V} 2$ 9,5;V38.25; V4 10.5, Jadi alternative keputusan pemilihan bibit salak yang di pilih adalah salak condet.

a. Desain Input Data Salak

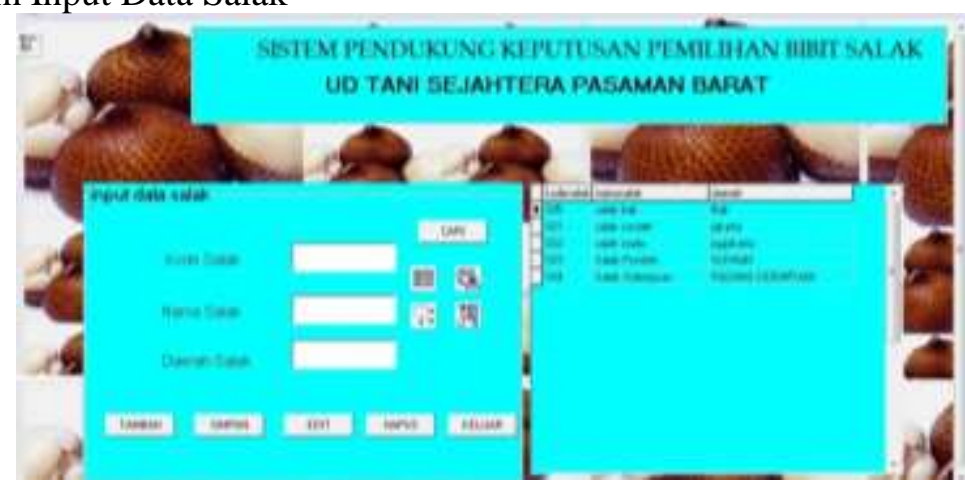

Gambar 7 Desain Form Input Data Salak

b. Desain Input Kriteria

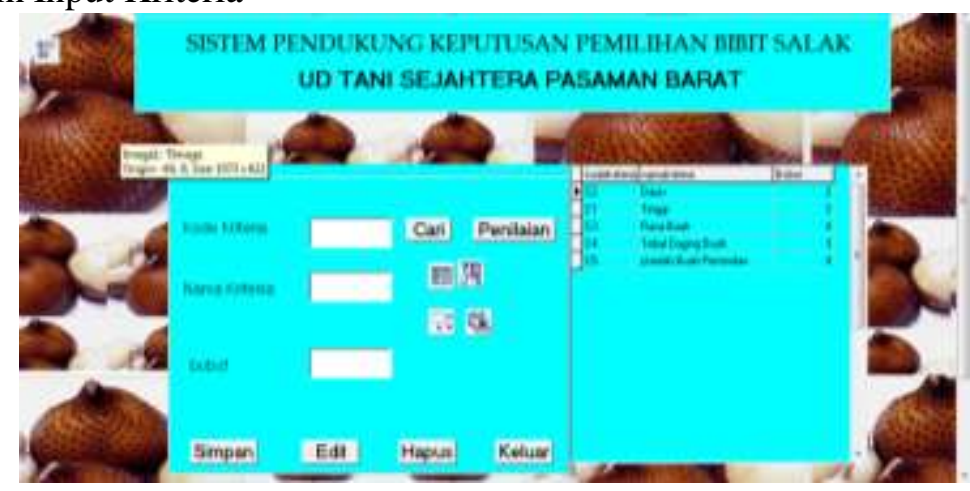

Gambar 8 Desain Form Input Kriteria

c. Desain Penilaian

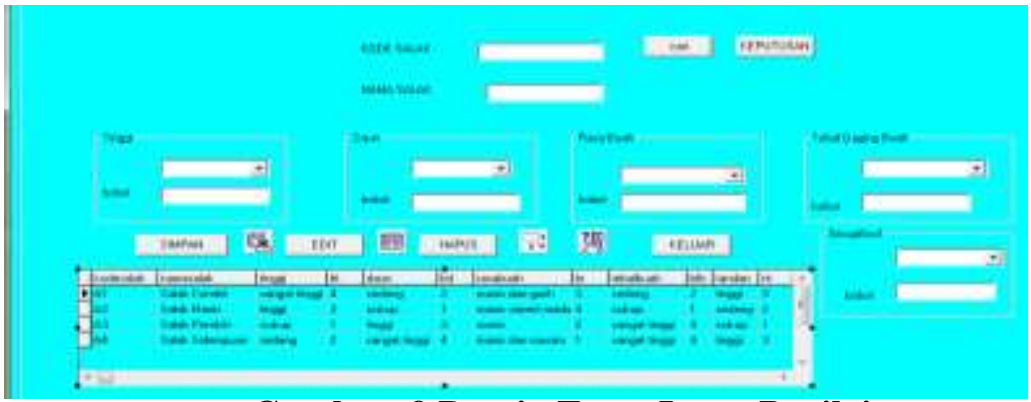

d. Desain Keputusan

\section{Gambar 9 Desain Form Input Penilaian}

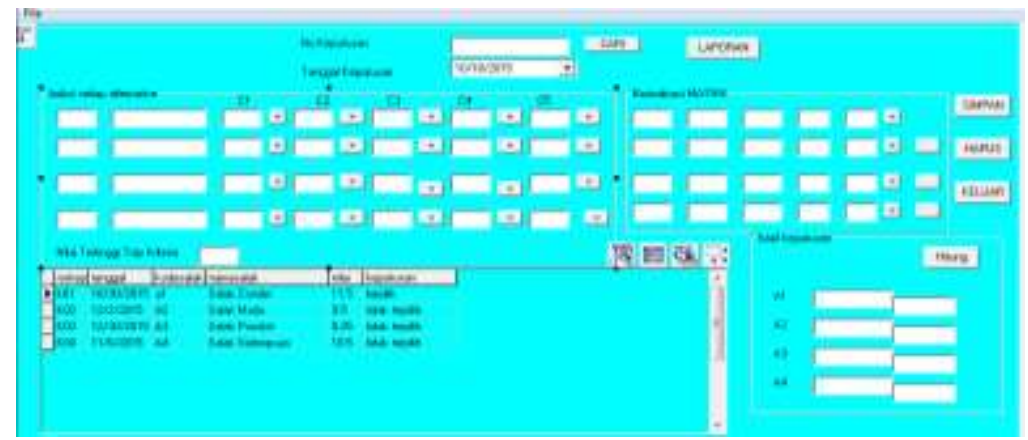

Gambar 10 Desain Form Keputusan 


\section{Desain Output}

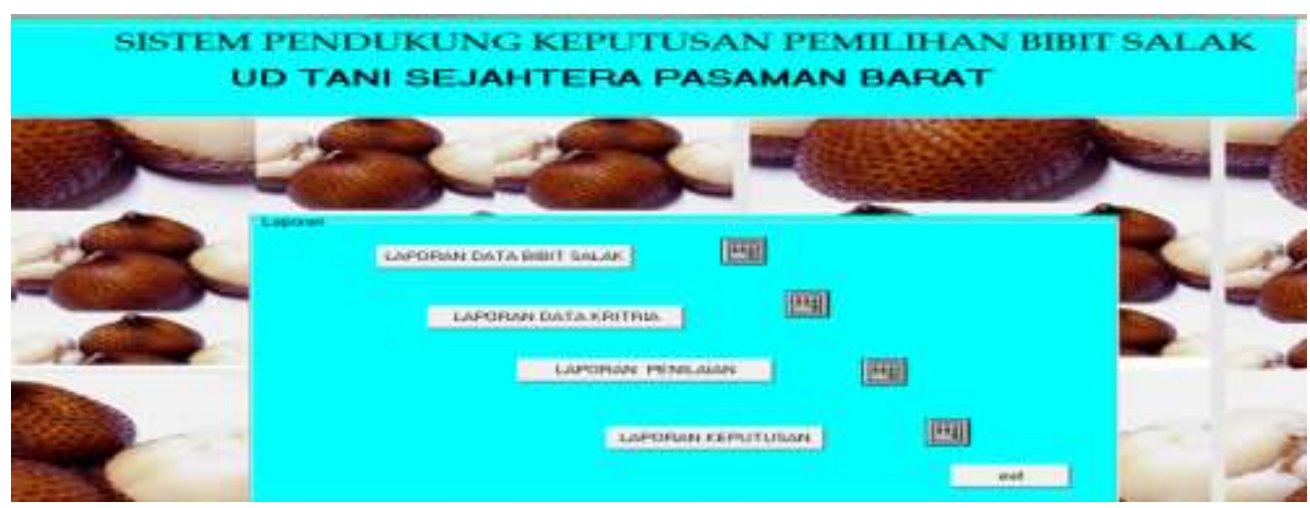

Gambar 12 Desain Output

Tabel. 10. File Data Salak, Nama tabel: salak, Field kunci: kodesalak

\begin{tabular}{|l|l|c|l|}
\hline \multicolumn{1}{|c|}{ Nama Field } & \multicolumn{1}{c|}{ Type } & Panjang & \multicolumn{1}{c|}{ Keterangan } \\
Kodesalak & Varchar & 5 & Kode salak \\
\hline Namasalak & Varchar & 20 & Nama salak \\
\hline Daerahsalak & Varchar & 20 & Daerah salak \\
\hline Idsuplier & Integer & & Id Suplier \\
\hline
\end{tabular}

Tabel. 11 File Keputusan, Nama tabel: Keputusan, Field kunci: Nokep

\begin{tabular}{|c|c|c|l|}
\hline Field & Type & Panjang & \multicolumn{1}{|c|}{ Keterangan } \\
Nokep & Varchar & 5 & No keputusan \\
\hline Tanggal & Date & 5 & Tanggal \\
\hline Kodesalak & Integer & 5 & Kodesalak \\
\hline Nama salak & Varchar & 5 & Nama salak \\
\hline Nilai & Integer & 5 & Nilai \\
\hline Keputusan & Varchar & 5 & Keputusan \\
\hline
\end{tabular}

\section{Flowchart Menu Utama}

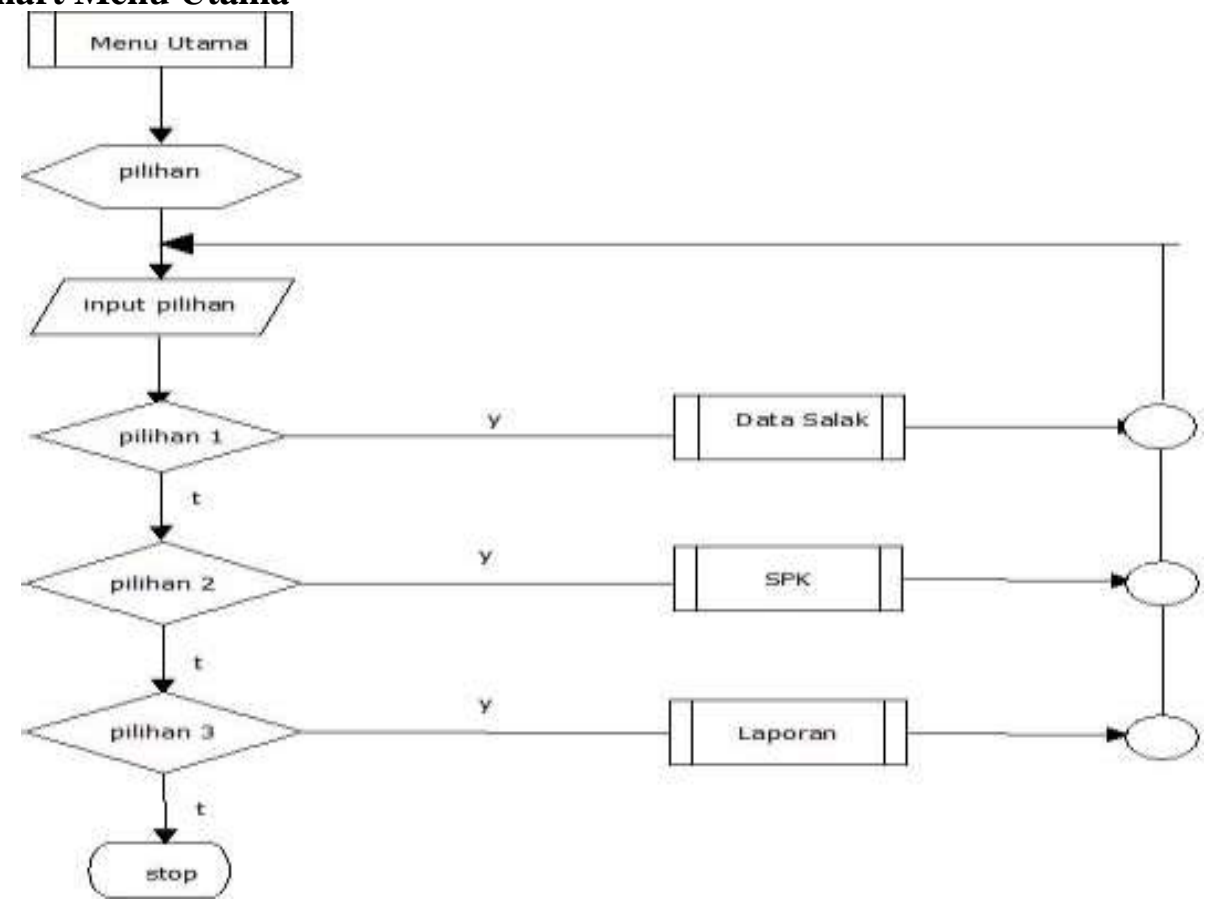

Gambar 13. Flowchart Menu Utama 
a. Flowchart Input Data Salak

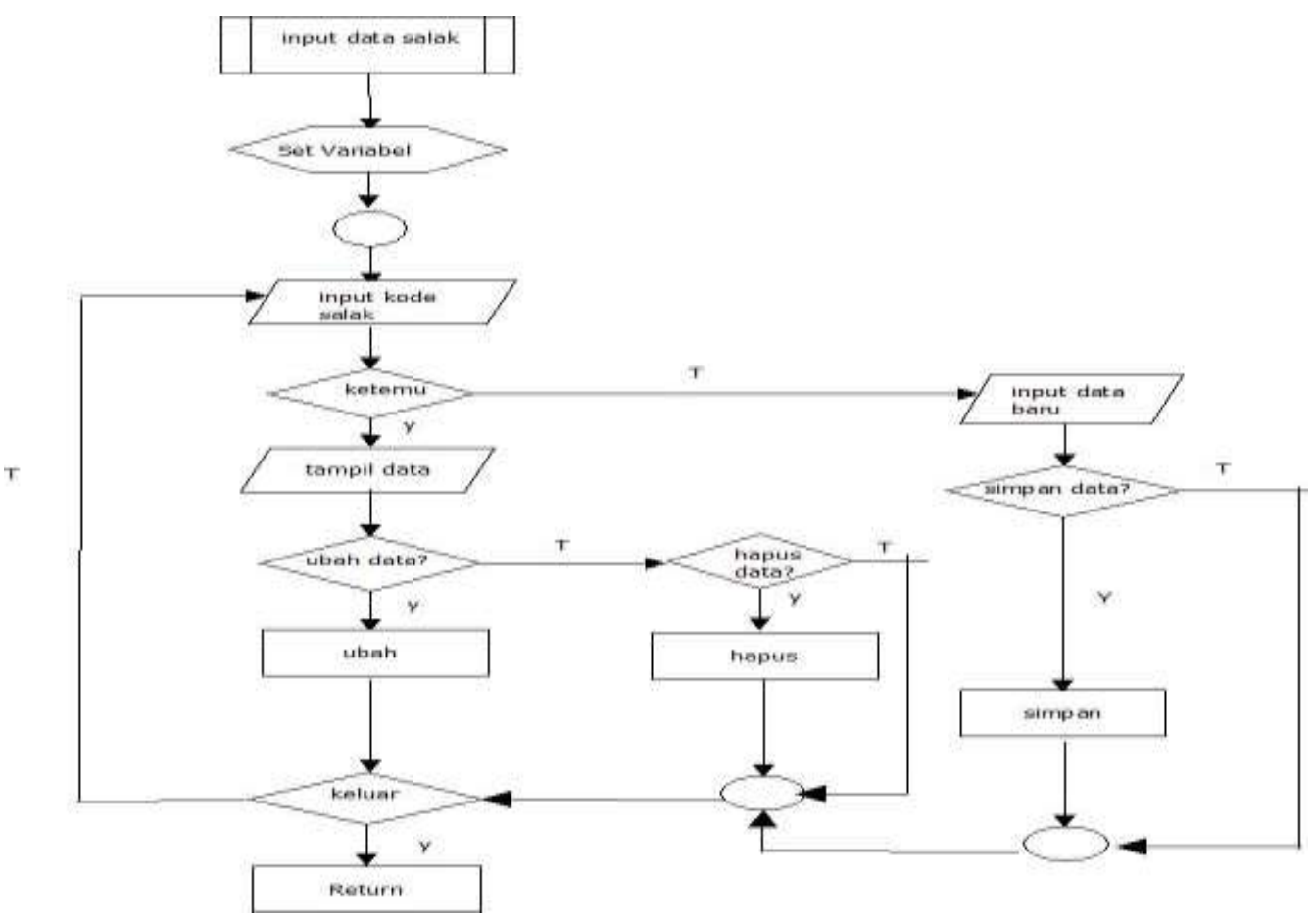

b. Flowchart Kriteria

Gambar 13. Input Data Salak

c. Flowchart Keputusan

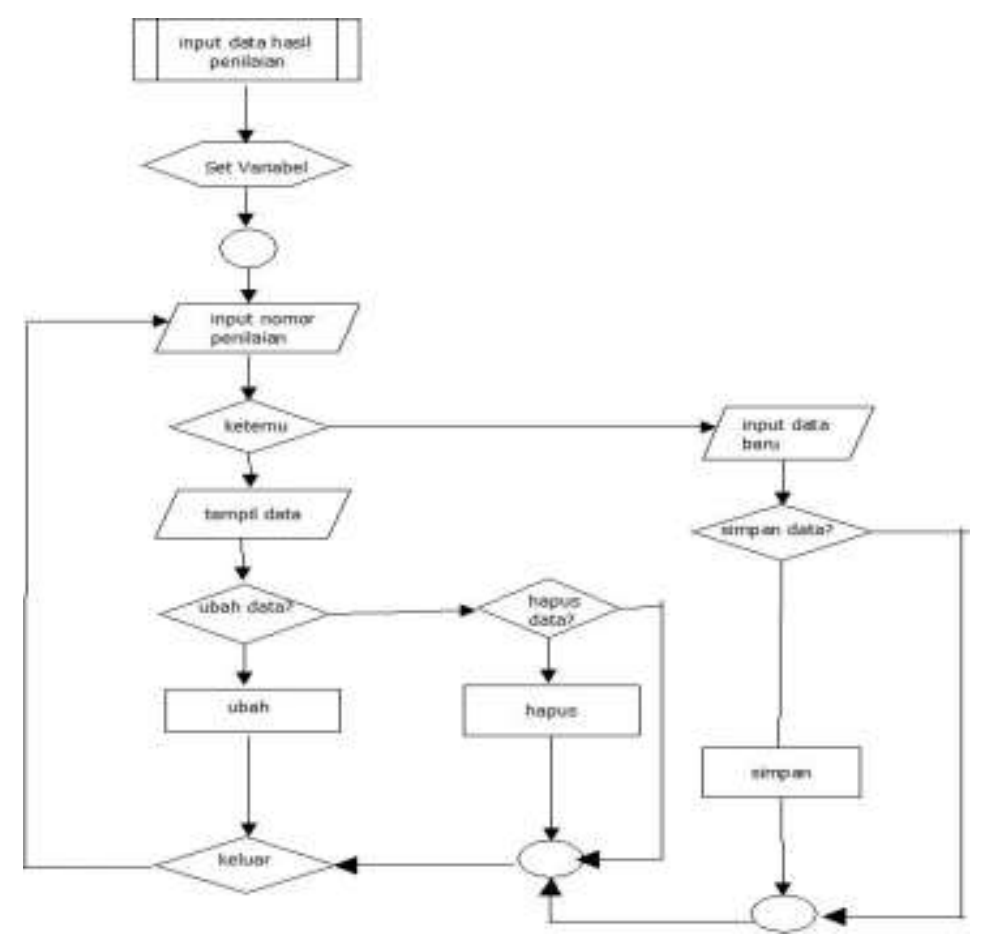

Gambar 14. Flowchart Keputusan 


\section{DAFTAR PUSTAKA}

Daihani, D.Umar. 2001. Komputerisasi Pengambilan Keputusan. PT Elex Media Komputindo, Jakarta

Fajar Nugraha.Sistem Pendukung Keputusan Evaluasi Pemilihan Pemenang Pengadaan Aset dengan Metode Simple Additive Weighting (SAW). Dari Jurnal SistemInformasiBisnis02(2012)Onlin: http://ejournal.undip.ac.id/index.php/j sinbis

Khamaludin, Asep Penentuan Penerimaan Beasiswa Dengan Menggunakan Metode SAW. Seminar nasional Informatika 2012.

Kusrini, 2007, "Konsep Dan Aplikasi Sistem Pendukung Keputusan", Yogyakarta, STMIK Amikom

Kussnassriyanto ,"Belajar Pemograman Delphi“, Penerbit Modula, Bandung, Agustus 2011.

Marakas, George M. "Decision Support Systems in the 21st Century", 2nd Edition, Prentice Hall, 2003

Sprague, Ralph, H \& Hugh, J. Watson, "Decision Support Systems", Prentice Hall, Inc., 1993

Turban, Efraim \& Aronson, Jay E., "Decision Support Systems and Intelligent Systems", 8th edition, Prentice Hall, Upper Saddle River, NJ, 2007

Turban, E. and Jay E.Aronson and Ting Peng Liang. 2005. Decision Support Systems and Intelligent Systems. Seventh Edition, Pearson PrenticeHall, New Jersey.

Suryadi, K. dan M.Ali Ramdhani. 1998. Sistem Pendukung Keputusan. PT. Remaja Rosdakarya, Bandung.

Yohana, Verina, \& Katrina sistem Pendukung Keputusan Untuk Menentukan Penerimaan Beasiswa dengan Metode SAW (Simple Additive Weighting). Jurnal Teknologi Informasi DINAMIK Volume 16, No. 2 , Juli 2012. 